\title{
No relation between EFHC2 gene polymorphism and Idiopathic generalized epilepsy.
}

\author{
Tuğrul Berrin ${ }^{1}$, Yılmaz Hikmet², Vatandaş Gülşen², Bozyiğit Ferda ${ }^{3}$, Balcan Erdal ${ }^{1}$, Onur Ece ${ }^{3}$
}

1. Celal Bayar University Faculty of Science and Letter, Molecular Biology.

2. Celal Bayar University Faculty of Medicine, Neurology.

3. Celal Bayar University Faculty of Medicine, Medical Biochemistry.

\begin{abstract}
:
Background: Idiopathic generalized epilepsy (IGE) is an epilepsy form without an underlying brain lesion or neurological indication or symptom. Recent investigations on the genetic origins of IGE and its subtypes report that certain mutations of various ion and non-ion channels genes in the central nervous system may be associated with IGE.

Purpose: In this study we evaluated the relation between IGE and S430Y polymorphism in EFHC2 gene in a Turkish population.

Material/methods: The study enrolled 96 healthy volunteers (47 male, 49 female), served as controls, and 96 IGE patients (41 male, 55 female), IGE diagnosis was confirmed in the neurology department. DNA extractions were performed. The presence of S430Y polymorphism in the exon 9 of EFHC2 gene were analyzed by Real-Time PCR. The findings obtained from the control and patient groups were compared.

Results: In the patient group there was one heterozygous male with $685 \mathrm{~T}>\mathrm{C}$ mutation. In the control group, there were two objects with $685 \mathrm{~T}>\mathrm{C}$ mutation; one heterozygous male, one heterozygous female. $662 \mathrm{G}>\mathrm{A}$ mutation was determined in neither controls nor patients.

Conclusion: In our series of 96 IGE patients and 96 healthy controls, there was no relation between S430Y polymorphism in EFHC2 gene and IGE presence.

Keywords: EFHC2 gene polymorphism, idiopathic generalized epilepsy.

DOI: http://dx.doi.org/10.4314/ahs.v15i4.20

Cite as: Berrin T, Hikmet Y, Gülssen V, Ferda B, Erdal B, Ece O. No relation between EFHC2 gene polymorphism and Idiopathic generalized epilepsy. Afri Health Sci. 2015;15(4):1204-10. http:/ / dx.doi.org/10.4314/abs.v15i4.20
\end{abstract}

\section{Introduction}

Idiopathic generalized epilepsies (IGEs) are characterized by recurring generalized seizures without any underlying structural cerebral lesion or other neurological finding ${ }^{1}$ and comprise approximately $70 \%$ of all epilepsy cases ${ }^{2}$.

According to the classification by the International League Against Epilepsy (ILAE), "idiopathic epilepsy (IE) syndrome is an age-dependent, pure epilepsy syndrome of predominately genetic origin in which there is no underlying anatomic or neurological abnormality"3. Numerous studies have assumed that genetic defects
Corresponding author:
Tuğrul Berrin,
Celal Bayar University Faculty of Science
and Letter, Molecular Biology
Email: berrin.tugrul@yahoo.com /
berrin.tugrul@cbu.edu.tr

play an essential role in the etiology of IGEs, and it has been reported that many IGE-related genes are responsible for encoding canal proteins ${ }^{4}$.

Recent studies indicated that the molecular mechanisms underlying the IGEs are mutations in some critical ion and non-ion channel protein encoding genes. Mutations in ME2, LGI4, EFHC1, and EFHC2, which encode non-ion channel proteins and KCNJ10, KCNJ3, KCNQ2/KCNQ3, CLCN2, GABRG2, GABRA1, SC$\mathrm{N} 1 \mathrm{~B}$, and SCN1A, which encode ion channel proteins have been implicated in epilepsy ${ }^{2}$.

The EFHC2 gene is mapped to chromosome Xp11.4; it contains 15 exons and encodes a 749-amino acid protein, and contains three DM10 domains and three calcium-binding EF-hand motives 5 . DM10-1 domain is located between amino acids 75-182 (108 amino acids), while the 143-amino acid containing DM10-2 and 108-amino acid containing DM10-3 domains are located between amino acids 226-368 and 431-538, respectively. The 36-amino acid containing EF-hand domain is located at a region within amino acids 558-593. Alter- 
native splicing produces two isoforms of the protein. The second isoform is a 162-amino acid product without the amino acids $1-587^{6}$.

$\mathrm{Gu}$ et al. reported a tentative relation between the S430Y polymorphism of EFHC2 gene in patients suffering from Juvenile Myoclonic Epilepsy (JME), an IGE sub syndrome, and epilepsy. They emphasized that independent replication studies are required to further analyse the relation between $\mathrm{S} 430 \mathrm{Y}$ polymorphism and $\mathrm{IGE}^{5}$. In this study, we have examined whether there is relation between S430Y polymorphism of EFHC2 gene and IGE.

\section{Material and methods \\ Patient and control groups}

Patient group: 42 male and 54 female patients, mean aged 31.35, diagnosed clinically with IGE at the Department of Neurology of Faculty of Medicine, Celal Bayar University were included in the study. In terms of seizure type, patients with IGE $(n=96)$ were tonic-clonic $(\mathrm{n}=77)$, absence $(\mathrm{n}=8)$, tonic $(\mathrm{n}=4)$, atonic $(n=3)$, myoclonic $(n=4)$. All patients gave fully informed consents to participate in the study, and $3 \mathrm{~mL}$ of a blood sample was taken from each of them.
Control group: 46 male and 50 female patients, mean aged 34.90, who presented to the Department of Neurology but did not have epilepsy or a condition which epilepsy-related genes are implicated comprised the control group. All control subjects gave fully informed consents to participate in the study, and $3 \mathrm{~mL}$ of blood samples were taken from them.

\section{Genomic DNA isolation}

Genomic DNA isolation was carried out in accordance with the manufacturer's protocol using $3 \mathrm{~mL}$ blood drawn from the subjects into collection tubes with EDTA (High Pure PCR Template Preparation Kit Ref\# 11796828001 Roche Diagnostics GmbH, Mannheim, Germany).

\section{Analysis of S430Y polymorphism in EFHC2 Gene by real-time PCR}

Using the extracted DNA, the design of the primers and probes used for the analysis of $\mathrm{G} / \mathrm{T}$ base substitution causing amino acid exchange S430Y in EFHC2 was undertaken by a commercial company (TIB MOLBIOL GmbH, Berlin, Germany) (Table1).

\section{Table 1: Primers and hybridization probes used to determine the}

S430Y polymorphism in EFHC2 gene

\begin{tabular}{|l|l|l|}
\hline Forward primer & rs2208592F & TGAAATGGTGTCATCACCGAGATA \\
\hline Reverse primer & rs2208592A & TTTCACTTTGGACAGTTTATGCCTAC \\
\hline $\begin{array}{l}\text { Fluorescent labeled } \\
\text { probe }\end{array}$ & rs2208592T & $\begin{array}{l}\text { GGAGTATATTGCTTTTGTAGCCAT- } \\
\text { FL* }\end{array}$ \\
\hline $\begin{array}{l}\text { Absorbance probe at 640 } \\
\text { nm wavelength }\end{array}$ & $\begin{array}{l}\text { Anc } \\
\text { rs2208592 }\end{array}$ & $\begin{array}{l}\text { G*640- } \\
\text { GCTAAATGGAAGAGAAATGAGAGTT } \\
\text { AGAGCp }\end{array}$ \\
\hline $\begin{array}{l}\text { *FL: Labeled with fluorescent from 3' end } \\
\text { *640 : Labeled with LightCycler Red 640 (LC Red 640) from 5' end }\end{array}$
\end{tabular}

LightCycler Faststart DNA Master Probe mix was obtained from a commercial company (Ref\# 03003248 001 Roche Diagnostics GmbH, Mannheim, Germany). PCR mix was prepared for the PCR reaction. PCR mix with a final volume of $20 \mu \mathrm{l}$ included $2 \mu \mathrm{l}$ forward primer $(0.5 \mu \mathrm{M}$ at $1 \mathrm{x}$ concentration), $2 \mu \mathrm{l}$ reverse primer ( 0.5 $\mu \mathrm{M}$ at $1 \mathrm{x}$ concentration), $2 \mu \mathrm{l}$ fluorescent-labeled probe
$(0.2 \mu \mathrm{M}$ at $1 \mathrm{x}$ concentration), $2 \mu \mathrm{l}$ LC Red 640 labeled probe $(0.2 \mu \mathrm{M}$ at $1 \mathrm{x}$ concentration), $2 \mu \mathrm{l}$ Taq DNA Polymerase $(1 \mathrm{x}), 3.4 \mu \mathrm{l}$ distilled water (H2O, PCR grade), 1.6 $\mu \mathrm{MgCl} 2$ (3mM at $1 \mathrm{x}$ concentration) and $5 \mu \mathrm{l}$ genomic template DNA $(5-25 \mathrm{ng} / \mu \mathrm{l})$. PCR reaction conditions are presented in Table 2. Melting curve analysis was gathered by LightCycler Software 3.05. 
Table 2: The analysis stages of realtime PCR using LightCyler 2.0 system

\begin{tabular}{|c|c|c|c|c|}
\hline $\begin{array}{l}\text { Analysis } \\
\text { Stages }\end{array}$ & $\begin{array}{l}\text { Number } \\
\text { of cycles }\end{array}$ & & Temperature $\left({ }^{\circ} \mathrm{c}\right)$ & Duration \\
\hline $\begin{array}{l}\text { Pre-incubation (To } \\
\text { activate Taq DNA } \\
\text { polymerase) }\end{array}$ & 1 & & 95 & 10 minutes \\
\hline \multirow{3}{*}{ PCR cycle } & \multirow{3}{*}{45} & Denaturation & 95 & 10 seconds \\
\hline & & Annealing & 58 & 10 seconds * \\
\hline & & Extension & 72 & 15 seconds \\
\hline \multirow{3}{*}{$\begin{array}{l}\text { Melting analysis (to } \\
\text { determine SNP) }\end{array}$} & \multirow{3}{*}{1} & Denaturation & 95 & 0 second \\
\hline & & Annealing & 40 & 30 seconds \\
\hline & & Melting & 85 & $0 \operatorname{second}^{* *}$ \\
\hline Cooling & 1 & & 40 & 30 seconds \\
\hline
\end{tabular}

* Single reading is taken to observe the amplification curve.

**Continuous reading with $0.2{ }^{\circ} \mathrm{C} / \mathrm{sec}$ ramp rate.

\section{Statistical analysis}

Student $\mathrm{T}$ test was used to compare the difference in mean ages between the patient and control groups. Chisquare test and Fisher's Exact Test were used for comparison of parameters related to $\mathrm{G}>\mathrm{T}$ polymorphism that caused amino acid exchange S430Y, for sex distribution and for within-group comparison of the data obtained from the patient group. The level of significance was set at $\mathrm{p}<0.05$ for both tests.

\section{Results}

\section{Genotyping}

Three different genotypes emerge when serine is substituted with tyrosine at position $430(\mathrm{~S} 430 \mathrm{Y})$ as a result of $\mathrm{G}>\mathrm{T}$ exchange at nucleotide 1289 of EFHC2 gene. Subjects with $G / G$ genotype (wild type) were normal, those with G/T genotype were heterozygote, and those with $\mathrm{T} / \mathrm{T}$ genotype were homozygote. EFHC2 is a gene found at X chromosome (Xp11.4).

While genotyping, hemizygote males with G>T polymorphism were considered homozygote since males have a single $\mathrm{X}$ chromosome.

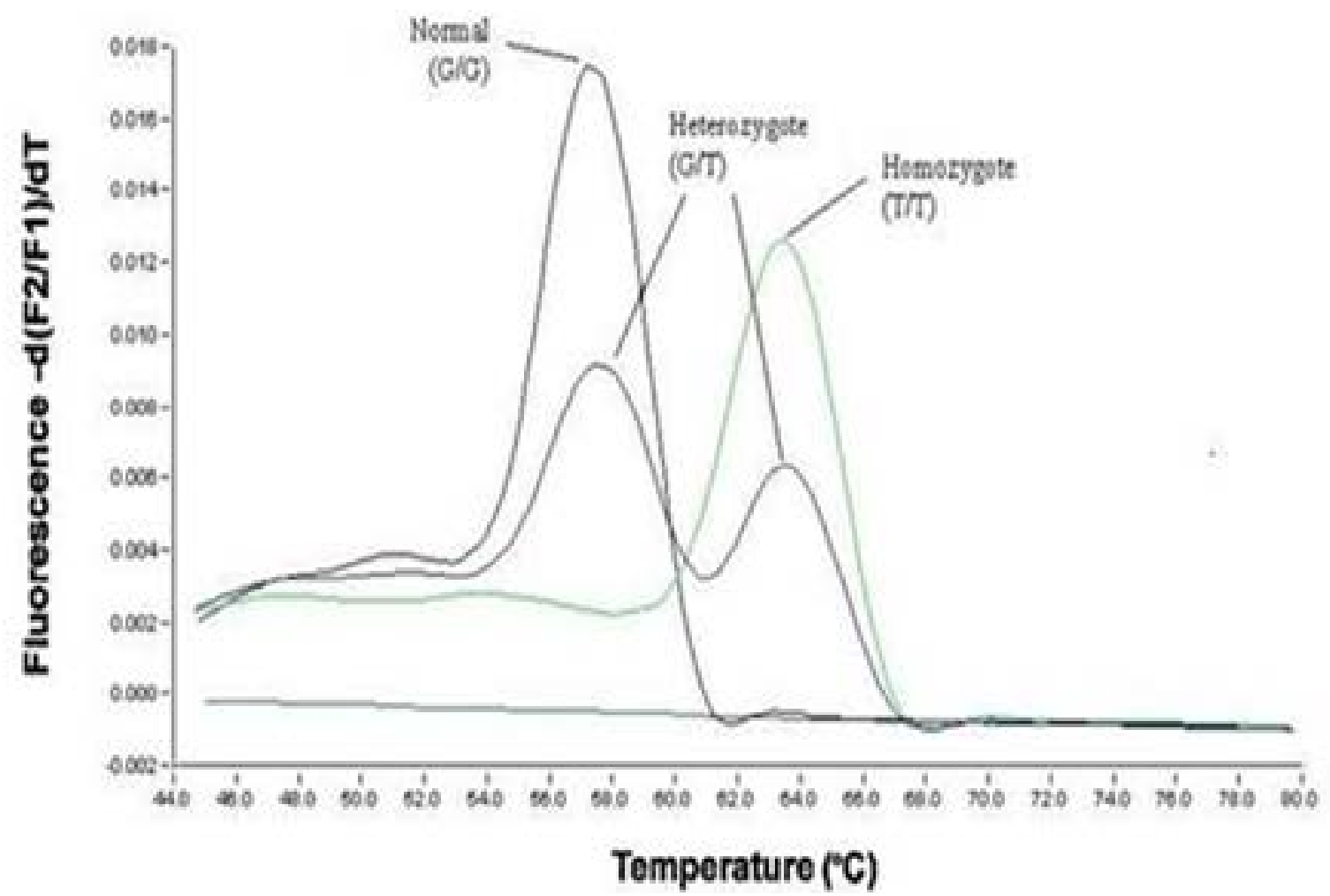

Figure 1: The results of Melting curve analysis that enabled genotyping using Light Cycler hybridization probe system and LC-Red 640 hybridization probe. 
According to the melting curve, the fluorescence signal is detected at $57^{\circ} \mathrm{C}$ for $\mathrm{G}$ and at $63.5^{\circ} \mathrm{C}$ for T. Genotyping is presented in Figure 1.
Statistical analysis

Table 3 depicts the data pertaining to the 96 patients di agnosed with IGE and 96 subjects in the control group.

Table 3: Parameters compared between patients and controls

\begin{tabular}{|c|c|c|}
\hline & Control & Patient \\
\hline $\mathbf{n}$ & $96(100 \%)$ & $96(100 \%)$ \\
\hline \multicolumn{3}{|l|}{ Sex } \\
\hline Male & $46(48 \%)$ & $41(43 \%)$ \\
\hline Female & $50(52 \%)$ & $55(57 \%)$ \\
\hline Mean age (years) & 34.90 & 31.35 \\
\hline \multicolumn{3}{|l|}{ S430y genotype } \\
\hline Normal & $84(88 \%)$ & $83(87 \%)$ \\
\hline Heterozygote & $8(8 \%)$ & $7(7 \%)$ \\
\hline Homozygote & $4(4 \%)$ & $6(6 \%)$ \\
\hline
\end{tabular}

Age, sex, type of IGE seizure, age at first seizure, family history of epilepsy and genotypes related to S430Y polymorphism in EFHC2 gene are presented in Table 4.

Table 4: Data related to the Patient Group

\begin{tabular}{lc}
\hline \multicolumn{2}{c}{ Patient group } \\
\hline N (number of subjects) & $96(100 \%)$ \\
Sex & Male \\
Female & $41(47 \%)$ \\
Mean age (years) & $55(53 \%)$ \\
Type of seizure & 31.35 \\
Tonic clonic & \\
Absence & $77(81 \%)$ \\
Tonic & $8(8 \%)$ \\
Atonic & $4(4 \%)$ \\
Myoclonic & $3(3 \%)$ \\
Family history of epilepsy & $4(4 \%)$ \\
Present & \\
Absent & $17(18 \%)$ \\
Age at first seizure $(\mathbf{x})$ & $79(82 \%)$ \\
X $\leq 16$ & $42(44 \%)$ \\
X $>16$ & $54(56 \%)$ \\
S430y genotype & $83(87 \%)$ \\
Normal $(\mathrm{g} / \mathrm{g})$ & $7(7 \%)$ \\
Heterozygote $(\mathrm{g} / \mathrm{t})$ & $6(6 \%)$ \\
Homozygote $(\mathrm{t} / \mathrm{t})$ &
\end{tabular}

Subjects in the patient group were divided into 3 groups in terms of age, namely "39 and under" "between 4059 " and" 60 and over". The relation between age group and type of seizure was assessed by Chi-square test and no significant relation was found $(\mathrm{p}>0.05)$ (Table 5). 
Table 5: Type of seizures with respect to age groups

Type of ige seizure

\begin{tabular}{|c|c|c|c|c|c|c|}
\hline \multirow[b]{2}{*}{ Age group } & \multicolumn{5}{|c|}{ Type of ige seizure } & \multirow[b]{2}{*}{ Total } \\
\hline & $\begin{array}{l}\text { Tonic } \\
\text { clonic }\end{array}$ & Absence & Tonic & Atonic & Myoclonic & \\
\hline $\begin{array}{l}39 \text { and } \\
\text { under }\end{array}$ & $\begin{array}{c}63 \\
(81.8 \%)\end{array}$ & $\begin{array}{c}6 \\
(7.8 \%)\end{array}$ & $\begin{array}{c}3 \\
(3.9 \%)\end{array}$ & $\begin{array}{c}2 \\
(2.6 \%)\end{array}$ & $\begin{array}{c}3 \\
(3.9 \%)\end{array}$ & $\begin{array}{c}77 \\
(100 \%)\end{array}$ \\
\hline $\begin{array}{l}\text { Between } \\
40-59\end{array}$ & $\begin{array}{c}10 \\
(90.9 \%)\end{array}$ & $\begin{array}{c}1 \\
(9.1 \%)\end{array}$ & - & - & - & $\begin{array}{c}11 \\
(100 \%)\end{array}$ \\
\hline $\begin{array}{l}60 \text { and } \\
\text { over }\end{array}$ & $\begin{array}{c}4 \\
(50 \%)\end{array}$ & $\begin{array}{c}1 \\
(12.5 \%)\end{array}$ & $\begin{array}{c}1 \\
(12.5 \%)\end{array}$ & $\begin{array}{c}1 \\
(12.5 \%)\end{array}$ & $\begin{array}{c}1 \\
(12.5 \%)\end{array}$ & $\begin{array}{c}8 \\
(100 \%)\end{array}$ \\
\hline Total & $\begin{array}{c}77 \\
(80.2 \%)\end{array}$ & $\begin{array}{c}8 \\
(8.3 \%)\end{array}$ & $\begin{array}{c}4 \\
(4.2 \%)\end{array}$ & $\begin{array}{c}3 \\
(3.1 \%)\end{array}$ & $\begin{array}{c}4 \\
(4.2 \%)\end{array}$ & $\begin{array}{c}96 \\
(100 \%)\end{array}$ \\
\hline
\end{tabular}

Presence of a relation between the type of IGE seizure in the Patient Group and S430Y polymorphism geno- type was tested by chi-square test, and we found that the difference was not statistically significant $(\mathrm{p}>0.05)$ (Table 6).

Table 6: The distribution of types of IGE seizures with respect to the S430Y genotype Type of ige seizure

\begin{tabular}{lcccccc}
$\begin{array}{l}\text { S430y } \\
\text { genotype }\end{array}$ & $\begin{array}{l}\text { Tonic } \\
\text { clonic }\end{array}$ & Absence & Tonic & Atonic & Myoclonic & Total \\
\hline G/g & 67 & 5 & 4 & 3 & 4 & 83 \\
& $(80.7 \%)$ & $(6 \%)$ & $(4.8 \%)$ & $(3.6 \%)$ & $(4.8 \%)$ & $(100 \%)$ \\
G/t & 5 & 2 & - & - & - & 7 \\
& $(71.4 \%)$ & $(28.6 \%)$ & & - & - & $(100 \%)$ \\
T/t & 5 & 1 & - & - & & 6 \\
& $(83.3 \%)$ & $(16.7 \%)$ & & & 4 & 96 \\
\hline \multirow{2}{*}{ Total } & 77 & 8 & 4 & 3 & $(100 \%)$ \\
\hline
\end{tabular}

\section{Discussion}

The genes calcium-binding EF-hand motifs 1 (EFHC1) and 2 (EFHC2) are responsible for the encoding of non-ion channel proteins which have been suggested to interact with ion channels, and hence they are associated with the development of epilepsy. Especially the amino acid exchange S430Y in exon 9 of EFHC2 was investigated in JME patients 5 . When the data obtained from our study was compared statistically, the differences between patient and control groups were found not to be significant $(\mathrm{p}>0.05)$.

However, due to the chromosomal location of the gene, male and female patients should be assessed separately in terms of S430Y polymorphism. Even though $\mathrm{X}$ chromosomal inheritance has not been identified among the complex genetic trait model of IGE syn- dromes, presence of a single $\mathrm{X}$ chromosome in males should be taken into consideration.

In German population, $\mathrm{Gu}$ and colleagues ${ }^{5}$ determined the polymorphisms in EFHC2 gene and their localizations. Also, authors reported a weak relation between S430Y (rs2208592) missense mutation and the epilepsy in 81 patients diagnosed with classical JME (without absence seizure), and they argued that S430Y polymorphism affected seizure susceptibility in male patients with $\mathrm{JME}^{5}$. In our study, 12 subjects in the control group ( 4 males and 8 females) and 13 patients (5 males and 8 females) in the patient group had S430Y polymorphism. When the control and patient groups were compared in terms of sex and presence of S430Y polymorphism, the differences were not statistically significant ( $\mathrm{p}>0.05)$. 
Types of seizures observed in IGE are tonic-clonic, myoclonic, atonic, tonic and absence seizures. Similar to generalized epilepsy with febrile seizures plus (GEFS + ), fever may also accompany seizures in some forms of IGE?

It has been argued that some genes involved in IGE had influence on the type of seizure as well. KCN1 ${ }^{8}$ and $\mathrm{KCNJ} 10^{9}$, two of the ion-channel genes, could be risk factors for seizure even though these genes did not have a major effect on the development of epilepsy.

In the present study, among the 96 IGE patients, 77 had tonic-clonic, 8 had absence, 4 had tonic, 3 had atonic and 4 had myoclonic seizure. There was no statistically significant relation between the type of seizure and carrier state for S430Y polymorphisms in EFHC2 in the patient group ( $\mathrm{p}>0.05)$.

In a previous study ${ }^{5}$, absence of a significant relation between JME and S430Y G>T polymorphism can be attributed to the presence of only 4 cases with JME during patient recruitment phase. Investigating S430Y amino acid exchange only in the JME group could yield different findings.

EFHC2 is the EFHC1 gene paralog in human genome. EFHC1 and EFHC 2 genes are expressed in cerebral neurons ${ }^{5}$. In our previous study, we found no evidence that EFHC1 is a major genetic factor for the development of IGE in Turkish patients, and we indicated that $685 \mathrm{~T}>\mathrm{C}$ and $662 \mathrm{G}>\mathrm{A}$ polymorphisms might not be associated with $\mathrm{IGE}^{10}$. Hence, we considered that examined polymorphisms (in genes EFHC1 and EFHC2) might not be a major genetic risk factor in terms of IGE.

Data pertaining to the SNP that causes S430Y exchange (rs2208592) can be found at the web pages of National Institute of Health Sciences ${ }^{11}$. This page lists S430Y genotype data obtained from 1245 patients from Asia, Europe, Africa, and various populations, and it shows that 956 patients had G/G, 71 had G/T, and 30 had $\mathrm{T} / \mathrm{T}$ genotype ${ }^{11}$. In our study, of the 96 patients, $83 \mathrm{had}$ G/G, 7 had G/T and 6 had T/T genotype, while 84 of 96 subjects in the control group had G/G, 8 had G/T, and 4 had $\mathrm{T} / \mathrm{T}$ genotype. Being the first published data on S430Y polymorphism in Turkish population, we believe that the results of the present study will contribute to the knowledge base.

\section{Conclusion}

Present study in which the relation between idiopathic generalized epilepsy and $\mathrm{G}>\mathrm{T}$ polymorphism resulting in S430Y amino acid exchange in EFHC2 is examined, one of the non-ion channel genes failed to show a statistically significant difference between the patient and control groups.

The data on S430Y polymorphism genotypes in IGE patients and control subjects in Turkish population determined by real time PCR is the first of its kind. Data obtained in this study has the potential to set the ground for future studies.

\section{Acknowledgements}

The author thanks to Scientific Investigation Project to Coordinate of Celal Bayar University (Project No: Fen 2008-079) for financial support.

\section{References}

1. Commission of Classification and Terminology of the International League Against Epilepsy. Proposal for revised classification of epilepsies and epileptic syndromes. Epilepsia 1989; 30:389-399. doi: 10.1111/ j.1528-1157.1989.tb05316.x

2. Heron SE, Scheffer IE, Berkovic SF, Dibbens LM, Mulley JC. Channelopathies in idiopathic epilepsy. Neurotherapeutics 2007;4(2):295-304. doi: 10.1016/j. nurt.2007.01.009

3. Engel J. A proposed diagnostic scheme for people with epileptic seizures and with epilepsy: Report of the ILAE task force on classification and terminology. Epilepsia 2001;42:796-803. doi: 10.1046/j.15281157.2001.10401.x

4. Weber YG, Lerche H. Genetic mechanisms in idiopathic epilepsies. Developmental Medicine \& Child Neurology 2008;50:648-654. doi: 10.1111/j.14698749.2008.03058.x

5. Gu W, Sander T, Heils A, Lenzen KP, Steinlein OK. A new EF-hand containing gene EFHC2 on Xp11.4: Tentative evidence for association with juvenile myoclonic epilepsy. Epilepsy Research 2005;66:91-98. doi: 10.1016/j.eplepsyres.2005.07.003

6.http: / / www.genecards.org/cgi-bin/carddisp. pl?gene=EFHC2. 24 May 2010.

7. Baulac S, Gourfinkel-An I, Couarch P, Depienne C, Kaminska A, Dulac O, Baulac M, LeGuern E, Nabbout R. A Novel locus for generalized epilepsy with febrile seizures plus in French families. Archives of Neurology 2008;65(7):943-951. doi: 10.1001/archneur.65.7.943 
8. Eunson LH, Rea R, Zuberi SM, Youroukos S, Panayiotopoulos CP, Liguori R, Avoni P, McWilliam RC, Stephenson JB, Hanna MG, Kullmann DM, Spauschus A. Clinical, genetic, and expression studies of mutations in the potassium channel gene KCNA1 reveal new phenotypic variability. Annals of Neurology 2000;48:647656. doi: 10.1002/1531-8249(200010)48:4<647::AIDANA12>3.0.CO;2-Q

9. Shang L, Lucchese CJ, Haider S,Tucker SJ. Functional characterisation of missense variations in the
Kir4.1 potassium channel (KCNJ10) associated with seizure susceptibility. Brain Research Molecular Brain Research 2005;139:178-83. doi: 10.1016/j.molbrainres.2005.05.003

10. Büyük İ, Tuğrul B, Yılmaz H, Onur E, Vatandaş G, Bozyiğit FD. Association Between Idiopathic Generalized Epilepsy and EFHC1 Gene Mutations of $662 \mathrm{G}>\mathrm{A}$ and $685 \mathrm{~T}>\mathrm{C}$. Turkiye Klinikleri J Med Sci 2012;32(5):1247-53. doi: 10.5336/medsci.2011-25681 11. http://www.ncbi.nlm.nih.gov/projects/SNP/snp_ ref.cgi? rs=2208592, 24 May 2010. 